\title{
BMJ Open Continuing professional development requirements for UK health professionals: a scoping review
}

\author{
Marek Karas (D , ${ }^{1}$ Nik J L Sheen, ${ }^{1}$ Rachel V North, ${ }^{1}$ Barbara Ryan, ${ }^{1}$ Alison Bullock ${ }^{2}$
}

To cite: Karas $M$, Sheen NJL, North RV, et al. Continuing professional development requirements for UK health professionals: a scoping review. BMJ Open 2020;10:e032781. doi:10.1136/ bmjopen-2019-032781

- Prepublication history and additional material for this paper are available online. To view these files, please visit the journal online (http://dx.doi. org/10.1136/bmjopen-2019032781).

Received 09 July 2019 Revised 27 January 2020 Accepted 30 January 2020

Check for updates

(C) Author(s) (or their employer(s)) 2020. Re-use permitted under CC BY-NC. No commercial re-use. See rights and permissions. Published by BMJ.

${ }^{1}$ School of Optometry and Vision Sciences, Cardiff University, Cardiff, South Glamorgan, UK ${ }^{2}$ School of Social Sciences, Cardiff University, Cardiff, UK

Correspondence to

Marek Karas;

karasm@cardiff.ac.uk

\section{ABSTRACT}

Objectives This paper sets out to establish the numbers and titles of regulated healthcare professionals in the UK and uses a review of how continuing professional development (CPD) for health professionals is described internationally to characterise the postqualification training required of UK professions by their regulators. It compares these standards across the professions and considers them against the best practice evidence and current definitions of CPD.

Design A scoping review.

Search strategy We conducted a search of UK health and social care regulators' websites to establish a list of regulated professional titles, obtain numbers of registrants and identify documents detailing CPD policy. We searched Applied Social Sciences Index and Abstracs (ASSIA), Cumulative Index to Nursing and Allied Health Literature (CINAHL), Medline, EMCare and Scopus Life Sciences, Health Sciences, Physical Sciences and Social Sciences \& Humanities databases to identify a list of common features used to describe CPD systems internationally and these were used to organise the review of CPD requirements for each profession.

Results CPD is now mandatory for the approximately 1.5 million individuals registered to work under 32 regulated titles in the UK. Eight of the nine regulators do not mandate modes of CPD and there is little requirement to conduct interprofessional CPD. Overall $81 \%$ of those registered are required to engage in some form of reflection on their learning but only $35 \%$ are required to use a personal development plan while $26 \%$ have no requirement to engage in peer-to-peer learning.

Conclusions Our review highlights the wide variation in the required characteristics of CPD being undertaken by UK health professionals and raises the possibility that CPD schemes are not fully incorporating the best practice.

\section{INTRODUCTION}

Across the four nations of the UK, national strategy documents ${ }^{1-5}$ identify the need for health and social care systems to adapt to the challenges of delivering services in the future with the aim of creating a more flexible, multidisciplinary workforce able to deliver new models of care with an increasing role for non-medical healthcare professions. ${ }^{6}$ Specific emphasis is made on the role of education, including continuing professional

\section{Strengths and limitations of this study}

The first scoping review of UK regulator defined continuing professional development (CPD) requirements for nearly 1.5 million registrants.

- The review includes direct comparisons of current regulator CPD requirements for 32 healthcare professional titles in the UK.

- A lack of detail about individual CPD requirements for Doctors of Medicine means that the review may not capture specific details for this large group of professionals as, uniquely, individual CPD requirements are defined by medical colleges, faculties and employers, instead of the regulator.

- CPD activity described is a minimum to fulfil regulator requirements; in reality, $\mathrm{CPD}$ activity is likely to be much broader and incorporate more hours than specified in this paper.

development (CPD), in the evolution of this work force with the stated aim of expanding multiprofessional credentialing to allow for expansion of professional roles across medical and non-medical professions. ${ }^{5}$

In the UK, standards of training for qualification and CPD for professionals are set by a range of profession specific regulators. ${ }^{7}$ There are currently 13 such regulators, 9 of which regulate mainly health professions with the others regulating social care professions. These organisations are independent of government and derive their powers to regulate from primary and secondary legislation. Professionals working within the UK National Health Service (NHS) are currently expected to adhere to the standards set by their individual regulatory bodies and this includes meeting requirements for $\mathrm{CPD}{ }^{8}$

This system of professional regulation is currently under review by the Department of Health $^{9}$ (the branch of the UK government concerned with the maintenance of public health) and regulators are being asked to ensure that prequalification training of new staff meets the need for a more flexible workforce. As stated in the NHS Long Term Plan 
for England, much of the development of the existing workforce will fall to continuing education (CE) and training (CET) or CPD programmes, unique to each professional group.

There have been international surveys of CPD requirements for selected healthcare professions ${ }^{10-14}$ but there is no current analysis of these requirements for UK health professions. At a time of regulatory change, when the role of CPD in healthcare workforce evolution has been clearly highlighted, this review describes the features of CPD required of these health professionals by their regulators and considers if these requirements conform to the best practice. By detailing these requirements for the whole UK healthcare workforce, we also hope to contribute to the broader understanding of how CPD systems are evolving in the UK and internationally.

\section{METHODS}

As the main aim of this paper is to present an analysis of the characteristics of CPD systems as described by the professional regulators, the primary sources of information were the websites and documentation of those regulators.

The published literature was consulted using a modified Preferred Reporting Items for Systematic Reviews and Meta-Analyses extension for Scoping Reviews (PRIS$\mathrm{MA}-\mathrm{ScR}$ ) checklist to answer the question 'What are the characteristics of postqualification training systems for healthcare professionals as described by the literature?' Search terms describing the regulated professional groups were combined with terms describing postqualification education and the descriptive terms: survey(s), characteristics, requirements and features. Only the title was searched, using the Boolean operators AND and OR combined with truncation and phrase searches. The following databases were searched: ASSIA, CINAHL, Medline, EMCare and Scopus Life Sciences, Health Sciences, Physical Sciences and Social Sciences \& Humanities. Only papers in English were considered and no date limit was set. Once duplicates had been removed, the titles and abstracts of 249 papers were scrutinised to identify if they described characteristics of postqualification training systems. At this point, only papers from 1990 onwards were included. In total, 48 papers were identified for detailed scrutiny and a list of common features applicable to regulatory requirements was abstracted and these were combined with the authors own understanding of how CPD systems are described. This list of common features was used to organise the findings of the review of regulators documentation.

A description of the search strategy and abstraction process used is included in online supplementary file 1.

A targeted search of the websites of the 13 health and social care regulators was carried out using a modified PRISMA-ScR checklist. Four of those regulators (Care Council for Wales, Northern Ireland Social Care Council, Social Work England and the Scottish Social Services
Council) which solely regulate social professionals, such as adult home care workers, childcare workers and qualified social workers, were excluded from this analysis as they do not regulate healthcare professionals. The websites of the remaining nine regulators were scrutinised to identify: a list of professional titles that the regulators regulated, the most current reports on registration numbers and documents detailing CPD policy.

Reports on registration numbers produced by the regulators were consulted to find out the total number of registered individuals with each regulator. Where registration numbers were not available, an individual request for the information was made directly to the registrar of the organisation.

The identified documents detailing current CPD policy were reviewed to establish the characteristics of the individual CPD schemes. Where web-based information on CPD requirements was not available or incomplete, the CPD lead for that organisation was contacted by the lead researcher and the information obtained by telephone interview or email correspondence. A description of this second search strategy used is included in online supplementary file 2 .

\section{Patient and public involvement}

We did not involve patients or public in our work given our specific aim.

\section{RESULTS}

This analysis identified 32 distinct healthcare professional titles. Table 1 details the names of the nine regulators, the professional titles they regulate and the total number of registrants with each regulator in 2018/2019.

The total number of individuals working under regulated titles in 2018/2019 was 1491032 (table 1). The General Dental Council's and the Nursing and Midwifery Council's reports on registered numbers make it clear that an individual can be registered under more than one title. It should be noted that the number of registrants in a profession is regularly updated throughout the year, so these figures are only indicative of current numbers.

In all but four cases (Chiropodists and Podiatrists, and Prosthetists and Orthotists), the titles listed were unambiguous in the roles they describe. In the case of Chiropodists and Podiatrists, it is generally accepted that the titles are interchangeable ${ }^{15}$ so the title was regarded as one for the purpose of this analysis. In the case of Prosthetists and Orthotists, the situation is more ambiguous as the titles listed describe two distinct roles. ${ }^{16}$ The undergraduate training for these roles is the same and an individual holding the qualification can carry out both regulated functions making alterations to CE marked protheses and making alterations to $\mathrm{CE}$ marked orthoses, the two titles were counted as one profession for the purpose of this analysis. Medical practitioners are commonly described as doctors, although this title is used by other professions and in academia. The title protected under law for a 
Table 1 Healthcare regulatory bodies, the professional titles they regulate and the number of professionals registered with them

\begin{tabular}{|c|c|c|c|}
\hline Regulatory body & Professional titles regulated & Number of registrants & $\begin{array}{l}\text { Registrants as } \\
\text { percentage of tota }\end{array}$ \\
\hline General Chiropractic Council ${ }^{53}$ & Chiropractors & 3220 (31 December 2017) $^{54}$ & $0.22 \%$ \\
\hline General Dental Council $^{55}$ & $\begin{array}{l}\text { Dental nurses } \\
\text { Dentists } \\
\text { Dental hygienists } \\
\text { Dental technicians } \\
\text { Dental therapists } \\
\text { Orthodontic therapists } \\
\text { Clinical dental technicians }\end{array}$ & $\begin{array}{l}58047 \\
40654 \\
7310 \\
5929 \\
3351 \\
634 \\
368 \\
\left(1 \text { January } 2019^{55}\right.\end{array}$ & $\begin{array}{l}3.89 \% \\
2.73 \% \\
0.49 \% \\
0.40 \% \\
0.22 \% \\
0.04 \% \\
0.02 \%\end{array}$ \\
\hline General Medical Council ${ }^{56}$ & Doctor of Medicine & 298864 (1 February 2019) & $20.04 \%$ \\
\hline General Osteopathic Council ${ }^{58}$ & Osteopaths & 5353 (2 January 2019) $)^{59}$ & $0.36 \%$ \\
\hline Nursing and Midwifery Council ${ }^{60}$ & $\begin{array}{l}\text { Nurses } \\
\text { Midwives } \\
\text { Nursing associate }\end{array}$ & $\begin{array}{l}653544 \text { nurses } \\
36916 \text { midwives } \\
489 \text { Nursing associates } \\
(31 \text { March 2019) }\end{array}$ & $\begin{array}{l}43.83 \% \\
2.49 \% \\
0.03 \%\end{array}$ \\
\hline General Pharmaceutical Council ${ }^{63}$ & $\begin{array}{l}\text { Pharmacists } \\
\text { Pharmacy technicians }\end{array}$ & $\begin{array}{l}55177 \text { pharmacists } \\
23381 \text { pharmacy technicians } \\
(11 \text { July 2018) }\end{array}$ & $\begin{array}{l}3.90 \% \\
1.57 \%\end{array}$ \\
\hline $\begin{array}{l}\text { Pharmaceutical Society of Northern } \\
\text { Ireland }^{64}\end{array}$ & Pharmacists in Northern Ireland & 2591 (4 February 2019) & $0.17 \%$ \\
\hline \multirow{10}{*}{ 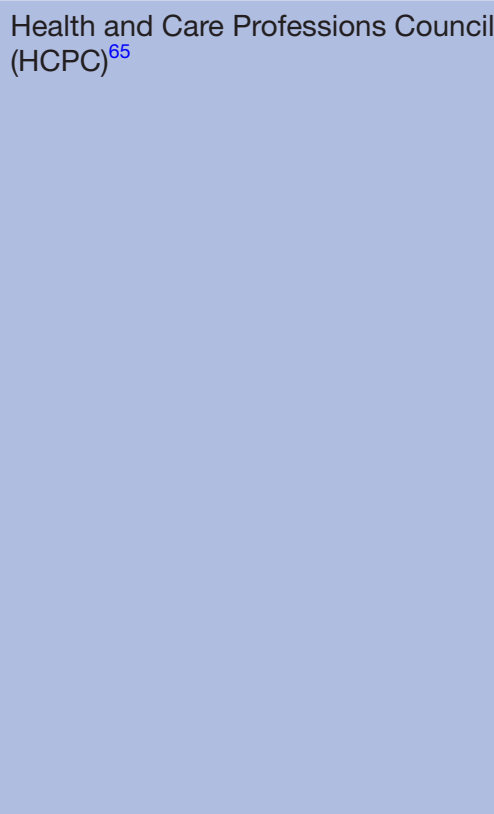 } & Physiotherapists & 55401 & $3.71 \%$ \\
\hline & Occupational Therapists & 39750 & $2.67 \%$ \\
\hline & Radiographers & 34358 & $2.67 \%$ \\
\hline & Dieticians & 9666 & $0.65 \%$ \\
\hline & Clinical Scientists & 6156 & $0.41 \%$ \\
\hline & Arts therapists & 4380 & $0.29 \%$ \\
\hline & Hearing Aid Dispensers & 2988 & $0.20 \%$ \\
\hline & Orthoptists & 1493 & $0.10 \%$ \\
\hline & Prosthetists and Orthotists & 1099 & $0.07 \%$ \\
\hline & & $\begin{array}{l}\text { (HCPC registrant numbers on } 1 \\
\text { January 2019) }\end{array}$ & \\
\hline $\mathrm{n}=9$ & $\mathrm{n}=32$ & Total=1 491032 & \\
\hline
\end{tabular}

${ }^{*}$ Registrar. Number of registrants (online). Email from goc@optical.org July 2018.

†Information requests. Number of registrants (online). Email from foi@pharmacyregulation.org July 2018.

$\ddagger$ Number of registrants (online). Email from info@psni.org.uk February 2019.

medical practitioner in the UK is 'Doctor of Medicine'17 and in this article we will use the term 'doctor' to mean Doctor of Medicine.

The detail of the CPD requirements for each regulator is set out in table 2. All the regulators use the term "Continuing Professional Development" abbreviated to
"CPD" except for the General Optical Council which uses the term "Continuing Education and Training" abbreviated to "CET". For all regulated professionals, CPD is a mandatory requirement of ongoing registration. With the exception of the General Chiropractic Council and the Health and Care Professions Council (HCPG), all 


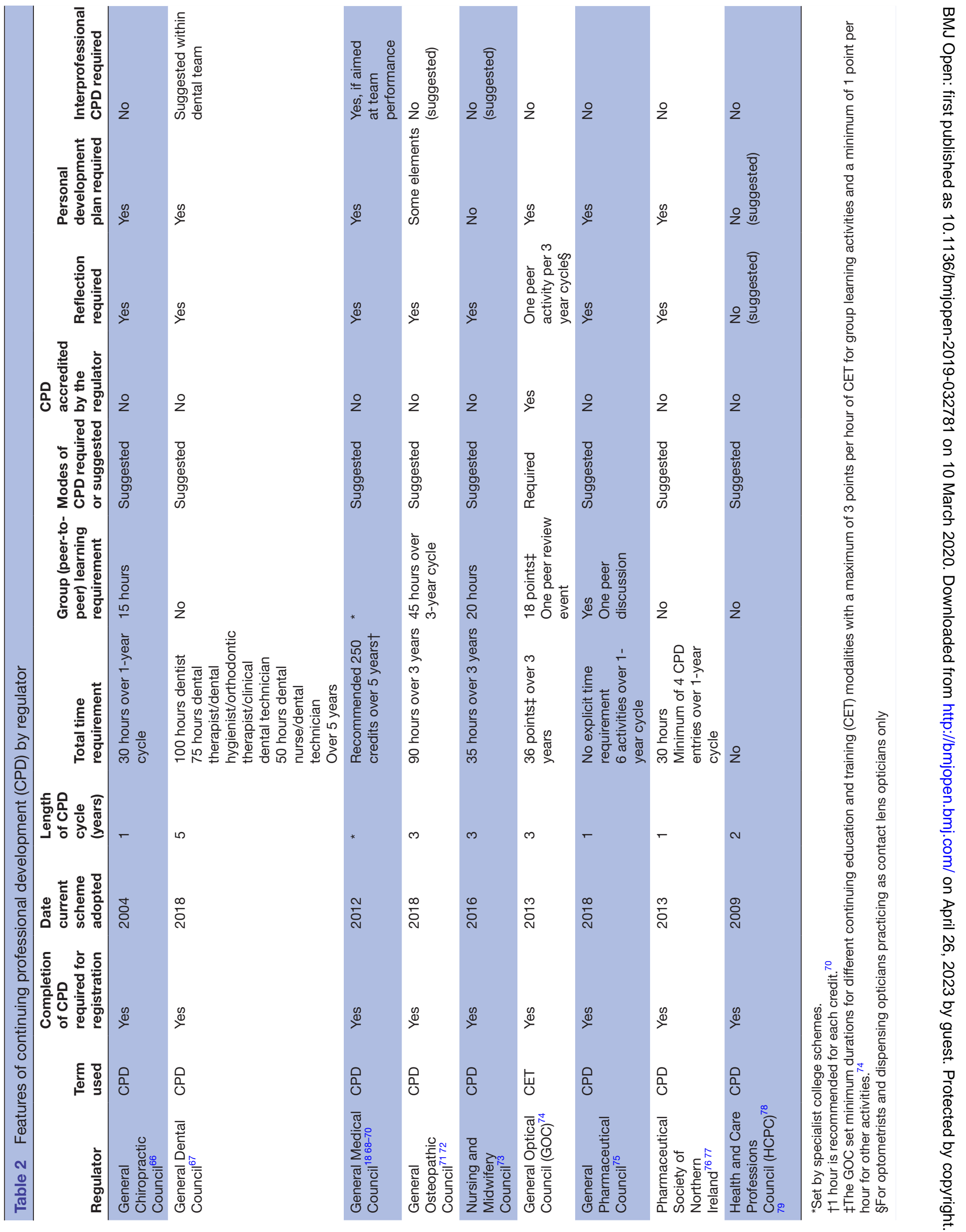


regulators have updated their CPD schemes since 2012; with the General Dental Council, the General Osteopathic Council and the General Pharmaceutical Council introducing revised schemes in 2018.

The length of the CPD cycle describes the period over which the requirements must be met, and these are of either annual cycles, 2-yearly, 3-yearly or 5-yearly cycles. With the exception of the HCPC, all the regulators specify the amount of CPD that needs to be completed over the cycle period either through a time target, specified activites or through the attainment of points that are allocated for activities based on type of activity and duration. If we consider the seven regulators which specify a time requirement over a given period, the calculated annual requirement ranged from 10 hours to 50 hours (mean 23 hours).

Learning with peers is required by five regulators: the General Chiropractic Council, General Osteopathic Council, Nursing and Midwifery Council, General Optical Council and General Pharmaceutical Council. The HCPC, Pharmaceutical Society of Northern Ireland and General Dental Council do not yet require group or peer learning, but they do suggest it as a type of CPD activity. The General Medical Council offers only broad CPD guidelines leaving the detail of CPD schemes to specialist colleges or employers. As this guidance states that practitioners should participate in peer-to-peer learning, it can be anticipated that individual specialist schemes will include this element, but we cannot confirm this is the case. Consequently, even though we cannot report on the proportion of registered professionals that are required to engage in peer-to-peer learning, we can report that 26\% (391 982) of professionals registered under a title are not required to do so.

The General Optical Council accredits all learning activities on an individual activity basis using a peer-review process and is therefore the only regulator that stipulates which modes of CPD are required but guidelines for the detailing of CPD schemes for doctors ${ }^{18}$ suggest that individual medical colleges or faculties may accredited CPD activities. All the other regulators do not accredit CPD activities but either offer a detailed list of the types (modes) of learning that are acceptable, ask for CPD undertaken to be described in detail or suggest a wide range is used without offering specific detail.

The term "reflection" is used by all the CPD schemes, describing either a reflection on future learning needs as embodied within a personal development plan (PDP) or a reflection on a learning activity after it has occurred.

A reflection on future learning needs, through the use of a PDP, is explicitly required by The General Chiropractic Council, the General Dental Council, the General Medical Council and the General Optical Council. The General Pharmaceutical Council, and the Pharmaceutical Society of Northern Ireland do not use the term PDP but require planned learning activities for part or all of their schemes that constitute, in our opinion, the key elements of a PDP; that is, the required documentation of identified learning needs informed by the wider context of a professional's practice and work situation with learning planned and completed to meet those needs. The HCPC highlight the value of a PDP but do not require it. The General Osteopathic Council require that potential future CPD activities are identified as part of a peer discussion at the end of each cycle but these are not then linked to completed learning activites. The Nursing and Midwifery Council do not mention PDPs in their guidance on CPD and revalidation but give registrants the option to identify and discuss learning needs as part of their reflective accounts. The large number of professionals and professional titles registered with these three regulators means that even though most regulators require a PDP (six out of the nine) overall only $35 \%$ (521 632) of professionals registered under a title and 13 professions (out of 32) are required to reflect on, plan and complete some or all of their future learning using one. Where a PDP is required, the expectations vary considerably and are detailed in table 3, which shows where preplanned learning was required, how this was informed, if it was documented and if, on completion, there was reflection on the learning meeting the need. In most cases, learning goals are informed and set by the learner only, with the exception of the General Medical Council which uses the PDP as part of its reaccreditation procedure, requiring input into learning goals from an appraiser, quality data, significant events data and patient feedback. It should be noted that many of the regulators suggest that a PDP is informed by a variety of sources, but they do not require this to be documented. All require a documented action plan for all, or part of the planned learning but the degree of reflection on the plan on completion is variable.

A reflection on learning once it has occurred, for some or all learning activities undertaken, is required by all the regulators except for the HCPC which suggests it and only requires it of those chosen to complete a CPD statement during audit. The General Optical Council requires reflection for optometrists but not for dispensing opticians in their core role. The General Medical Council, the General Osteopathic Council and the Nursing and Midwifery Council are the only regulators that require this postlearning reflection to be discussed with a third party, an appraiser in the case of doctors, another registrant in the case of nurses and midwifes, or a peer in the case of osteopaths. This means that overall 81\% (1 211 211) of professionals registered under a title are required to reflect on at least some of their undertaken learning.

Taking part in CPD activities alongside other professionals is mentioned by only four regulators. The Nursing and Midwifery Council, General Osteopathic Council and General Dental Council suggest it, and the General Medical Council require it in situations where the training is aimed at improving multiprofessional team performance. The descriptions offered by these regulators would suggest that this is interprofessional learning, that is where professions learn with, from and about 
Table 3 Requirements of personal development plans by regulator

\begin{tabular}{llllll}
$\begin{array}{l}\text { General } \\
\text { Chiropractic } \\
\text { Council }^{66}\end{array}$ & $\begin{array}{l}\text { General } \\
\text { Dental } \\
\text { Council }^{67}\end{array}$ & $\begin{array}{l}\text { General } \\
\text { Medical } \\
\text { Council }^{6880}\end{array}$ & $\begin{array}{l}\text { General } \\
\text { Optical } \\
\text { Council }^{74}\end{array}$ & $\begin{array}{l}\text { General } \\
\text { Pharmaceutical } \\
\text { Council }^{75}\end{array}$ & $\begin{array}{l}\text { Pharmaceutical } \\
\text { Society of Northern } \\
\text { Ireland }^{7677}\end{array}$ \\
\hline
\end{tabular}

Who sets the learning goals and how are they informed?

\begin{tabular}{|c|c|c|c|c|c|c|}
\hline Learner only & $\checkmark$ & $\checkmark$ & & $\checkmark$ & $\checkmark$ & $\checkmark$ \\
\hline $\begin{array}{l}\text { With mandatory input } \\
\text { from third parties: } \\
\text { facilitators, appraisers, } \\
\text { tutors or colleagues }\end{array}$ & & & $\checkmark$ & & & \\
\hline $\begin{array}{l}\text { Is there a documented } \\
\text { CPD action plan linked to } \\
\text { learning activities? }\end{array}$ & $\checkmark$ & $\checkmark$ & $\checkmark$ & $\begin{array}{l}\checkmark \\
\text { For one } \\
\text { activity }\end{array}$ & $\begin{array}{l}\text { For } 2 \text { of } 4 \\
\text { required CPD } \\
\text { activities }\end{array}$ & $\checkmark$ \\
\hline
\end{tabular}

CPD, continuing professional development.

each other to improve collaboration and the quality of care. ${ }^{19}$ The General Dental Council suggest team-based learning within the dental team, which would suggest this is intradisciplinary learning that is learning undertaken within the discipline of dentistry.

All the regulators require that a record or declaration of CPD activities is submitted as part of their CPD accreditation process. In the case of the HCPC, each professional is required to keep an individual $\log$ of activity, but this is only verified if they are chosen for audit. The 15 healthcare professions regulated by the HCPC have a range of professional membership organisations that they are able to join, and most of these are detailed in table 4 . These organisations offer support in recording CPD via websites or through the provision of documentation such as logbook templates, but with the exception of the Society of Radiographers and the Royal College of Speech and Language Therapists (RCSLT), we were not able to identify additional CPD requirements made as a requirement of membership. The Society of Radiographers and the RCSLT run mandatory CPD schemes that meet the CPD requirements of the HCPC.

All the regulators have a mechanism for verifying that CPD has been undertaken with most using a random sample or chosen selection of a percentage of registrants. In the case of the General Optical Council, all CET activities are accredited, and participation is independently verified by course organisers. A record of participation is kept on an online portal which tracks progress over the CET cycle, so this can be considered full verification of all activities for all registrants. The detail of how CPD is recorded and verified by each regulator is set out in table 5 .

\section{DISCUSSION}

In consulting the websites of the regulators, we found easily accessible, well-documented information available about the titles regulated, their CPD requirements and schemes and total numbers of registrants.

We identified that there are 32 distinct healthcare professional titles regulated in the UK as defined by regulatory bodies. Our data on the total number of individuals registered with regulators and numbers of individuals registered under each title offer an alternative way of considering the numbers of people working within the healthcare system in the UK, a notoriously difficult figure to establish. ${ }^{20}$ Our review shows the total number of individuals maintaining a current registration across all the regulated professions but does not give an account of whole-time equivalents and so may be seen as a maximum. This offers an accurate guide to the total potential healthcare workforce in the UK, a number encompassing both those working in the state and independent sector.

There are many similarities between the requirements and characteristic of CPD schemes but also some notable differences.

For all the regulated professions, CPD is now a mandatory requirement of ongoing registration and participation is verified by, in the main, scrutiny of a sample of practitioner-maintained records. Participation in CPD for regulated professions was first suggested in 'Trust, assurance and safety: The regulation of health professionals ${ }^{21} \mathrm{a}$ government White Paper which set out a programme of reform for the UK's regulators in July 2006 in response to reports recommending measures to improve and enhance clinical governance in the $\mathrm{NHS}^{22}$ and over the last decade CPD has become a component of revalidation for many health professions. ${ }^{23}$ Even though work on the perceptions and attitudes to CPD among the professions have identified various perceived barriers to participation, ${ }^{24-27}$ including some ambivalence about mandatory schemes, ${ }^{28}$ this analysis shows that compulsory CPD is now a reality for all regulated UK professionals. 
Table 4 Professional bodies representing professions regulated by the Health and Care Professions Council

\begin{tabular}{|c|c|}
\hline Profession & Professional body \\
\hline Arts therapists & $\begin{array}{l}\text { British Association of Arts } \\
\text { Therapists }^{81}\end{array}$ \\
\hline Biomedical Scientists & $\begin{array}{l}\text { Institute of Biomedical } \\
\text { Science }^{81}\end{array}$ \\
\hline Chiropodists/Podiatrists & $\begin{array}{l}\text { College of Podiatry } \\
\text { British Chiropody and } \\
\text { Podiatry Association } \\
\text { Institute of Podiatrists and } \\
\text { Chiropodists }^{84}\end{array}$ \\
\hline Clinical Scientists & $\begin{array}{l}\text { Association of Clinical } \\
\text { Scientists }^{85}\end{array}$ \\
\hline Dieticians & British Dietetic Association ${ }^{86}$ \\
\hline Hearing Aid Dispensers & $\begin{array}{l}\text { British Society of Hearing Aid } \\
\text { Audiologists }^{87}\end{array}$ \\
\hline Occupational Therapists & $\begin{array}{l}\text { Royal College of } \\
\text { Occupational Therapists }{ }^{88}\end{array}$ \\
\hline $\begin{array}{l}\text { Operating Department } \\
\text { Practitioners }\end{array}$ & $\begin{array}{l}\text { College of Operating } \\
\text { Department Practitioners }{ }^{89}\end{array}$ \\
\hline Orthoptists & $\begin{array}{l}\text { British and Irish Orthoptic } \\
\text { Society }{ }^{9091}\end{array}$ \\
\hline Paramedics & College of Paramedics ${ }^{92}$ \\
\hline Physiotherapists & $\begin{array}{l}\text { Chartered Society of } \\
\text { Physiotherapy }\end{array}$ \\
\hline Practitioner Psychologists & $\begin{array}{l}\text { British Psychological } \\
\text { Society }^{94} \\
\text { Association of Educational } \\
\text { Psychologists }^{95}\end{array}$ \\
\hline Prosthetists and Orthotists & $\begin{array}{l}\text { British Association of } \\
\text { Prosthetists \& Orthotists }{ }^{96}\end{array}$ \\
\hline Radiographers & Society of Radiographers ${ }^{97}$ \\
\hline $\begin{array}{l}\text { Speech and Language } \\
\text { Therapists }\end{array}$ & $\begin{array}{l}\text { Royal College of Speech and } \\
\text { Language Therapists }^{98}\end{array}$ \\
\hline
\end{tabular}

Apart from one regulator, the General Optical Council, the term CPD is used by the regulators to describe their schemes and in all cases the regulators offered definitions of CPD within their guidance documents which highlighted the role of CPD in maintaining professional competence and ensuring professional development over an individual's working career. Numerous terms have been used over time to describe postqualification training and education: $\mathrm{CE}$, continuing medical education (CME), competency-based medical education (CBME) CET and CPD. CE, in medicine termed CME and the more recently as CBME, ${ }^{29}{ }^{30}$ is generally accepted to refer to specific educational activities that aim to update skills and understanding to maintain professional competence. ${ }^{1131} \mathrm{CE}$ has, in the past, formed the basis of voluntary or mandatory time or point-based education systems used by professional bodies ${ }^{31}{ }^{32}$ but over the last two decades there has been a shift to the use of the term CPD to describe these systems. ${ }^{11}{ }^{32}{ }^{33}$ In contrast to
CE, CPD has a much broader ambition of developing a wider range of skills beyond those core skills needed for continuing practise, aiming to develop the individual across their whole career. Crucially, it is a self-directed reflective approach centred around the practitioner. ${ }^{113}$ CPD contains CE as a key element but it requires the practitioner to consider engaging in structured learning activities beyond those aimed at just addressing specific learning needs. ${ }^{29}{ }^{34}$ It asks the practitioner to reflect on their own practise, identify their own individual learning needs, plan to meet these needs and then evaluate their learning while documenting this cycle in a PDP or portfolio. ${ }^{31} 35$ This move to CPD has been driven by the suggestion that the positive effects of $\mathrm{CE}$ on practitioner behaviours and patient outcomes ${ }^{37}$ can be improved on using the broader scope of CPD, although what constitutes effective CPD is still very much in question. ${ }^{38-40}$

So, if CPD is characterised by a cycle of reflection, planning, learning and evaluation, documented by a PDP, do CPD schemes for UK professionals have this as a requirement? The health regulators have recently acknowledged the importance of being a reflective practitioner ${ }^{41}$ and we found that all the regulators require or suggest some form of documented reflection. This is most often asked for after training activities have been completed to reflect on what has been learnt, and less for prospectively planning wider learning needs within a recognisable PDP. Thus, for most UK professionals, reflection on past learning, a characteristic of $\mathrm{CE}$, is a requirement but the future planning of learning needs through reflection, a key characteristic of CPD, is not.

Further to this, our review shows that the use of PDPs, recommended within UK health services for some time ${ }^{42}$ is not universal and when used they are mostly self-directed and self-evaluated. Only in medicine, it is a requirement that the PDP is informed by objective practice data and evaluated by an appraiser, a model other professions might consider moving towards to help drive learning and improve practise. Hence, although the inclusion of PDPs in formal appraisal has been recommended for allied health professionals in some extended roles, ${ }^{43}$ we would suggest that most non-medical health professions are not fully using the potential of PDPs as defined by accepted definitions. ${ }^{44}$

More variation between the schemes was evident in the modes of learning activities that were acceptable as CPD. It has been suggested that modes of training that involve group or peer learning are more effective at influencing practitioner behaviour ${ }^{38}$ and this type of learning can encompass a wide range of activities beyond the lecture room, such as learning with peers in the work place. This type of learning is mandated by five of the regulators but the only qualifying feature being that the learning activity is carried out with peers. The assumption can be made that these activities could occur in the workplace in the form of, for example, small group sessions or rounds or through attendance of external events such as conferences. In four of these cases, engagement in 
Table 5 Recording and verification of continuing professional development (CPD) by regulators

\begin{tabular}{|c|c|c|c|c|}
\hline Regulator & $\begin{array}{l}\text { CPD log/ } \\
\text { declaration } \\
\text { submitted by } \\
\text { all }\end{array}$ & $\begin{array}{l}\text { Online record of } \\
\mathrm{CE} / \mathrm{CPD} \text { offered } \\
\text { by regulator }\end{array}$ & $\begin{array}{l}\text { CPD record } \\
\text { verification } \\
\text { process }\end{array}$ & $\begin{array}{l}\text { Verification/ audit of CPD } \\
\text { record }\end{array}$ \\
\hline General Chiropractic Council (GCC) 6699 & Yes & Yes & Yes & $\begin{array}{l}\text { Randomly chosen records } \\
\text { audited by GCC }\end{array}$ \\
\hline General Dental Council (GDC) $)^{67}$ & Yes & Yes & Yes & $\begin{array}{l}\text { Randomly selected records } \\
\text { audited by GDC }\end{array}$ \\
\hline General Medical Council 80100101 & $\begin{array}{l}\text { Yes } \\
\text { By appraisal/ } \\
\text { revalidation } \\
\text { process }\end{array}$ & Yes & $\begin{array}{l}\text { Yes. By } \\
\text { appraisal/ } \\
\text { revalidation } \\
\text { process }\end{array}$ & $\begin{array}{l}\text { Not by GMC } \\
\text { Verification carried out as } \\
\text { part of revalidation }\end{array}$ \\
\hline General Osteopathic Council (GOsC) ${ }^{71}$ & Yes & Yes & Yes & $\begin{array}{l}\text { Randomly selected records } \\
\text { audited by GOsC }\end{array}$ \\
\hline $\begin{array}{l}\text { Nursing and Midwifery Council (NMC) } \\
102\end{array}$ & Yes & Yes & Yes & $\begin{array}{l}\text { Confirmer used as part of } \\
\text { revalidation. } \\
\text { NMC randomly selects } \\
\text { records for audit }\end{array}$ \\
\hline General Optical Council ${ }^{74}$ & Yes & Yes & Yes & $\begin{array}{l}\text { All records online and only } \\
\text { accredited CET used }\end{array}$ \\
\hline $\begin{array}{l}\text { General Pharmaceutical Council } \\
(\text { GPhC) }\end{array}$ & Yes & Yes & Yes & $\begin{array}{l}\text { Random and selected sample } \\
\text { of records audited by GPhC }\end{array}$ \\
\hline $\begin{array}{l}\text { Pharmaceutical Society of Northern } \\
\text { Ireland (PSNI) }\end{array}$ & Yes & Yes & Yes & $\begin{array}{l}\text { Minimum } 10 \% \text { sampled for } \\
\text { audit by PSNI }\end{array}$ \\
\hline $\begin{array}{l}\text { Health and Care Professions Council } \\
103\end{array}$ & Yes & No & Yes & $\begin{array}{l}\text { Random sample of } 2.5 \% \\
\text { registrants selected for audit }\end{array}$ \\
\hline
\end{tabular}

CE, continuing education; CET, continuing education and training.

group activities is significant, with around half of learning needing to be with peers. In contrast, three of the regulators make no requirement for group learning at all.

There is even less uniformity in the actual modes of CPD required, group or otherwise, with only one regulator, the General Optical Council setting out detailed guidelines for what is acceptable as CPD and then accrediting each activity before it happens. Individual colleges of medicine or faculties may accredit CPD, but this is not done by the regulator, the General Medical Council. The other seven regulators only suggest the modes of learning that are acceptable, and the onus is then on the registrant to ensure that the CPD activity is of adequate quality and relevant to their learning needs. These regulators have therefore only a limited insight and influence on the content, design and quality of the CPD being undertaken by their registrants basing their scrutiny of activities on the learners' records after the fact, as part of their verification processes. Given that the evidence base for what constitutes effective CPD is still developing, ${ }^{45}{ }^{46}$ it is possibly understandable that specified modes of CPD are not yet mandated by the regulators but as our review shows CPD is now a mandatory component of revalidation and is likely to become central to future accreditation of multidisciplinary teams. ${ }^{30}$ Consequently, the considerable organisational challenge of accrediting all CPD activities before they occur may become a necessity if content and quality are to be assured.

Given current moves to increase integration of NHS services at an organisational and clinical level, a requirement to conduct CPD alongside other professions is notably absent. The General Medical Council requires learning alongside colleagues when the CPD is aimed at improving team performance but as the details of CPD schemes organised by specialist colleges or employers were beyond the scope of this analysis we cannot say if this is widespread practise. The other regulators acknowledge the importance of learning alongside other professions ${ }^{41}$ but a requirement to do so is absent. Integration of NHS services is occurring at an organisational level in the form of new Integrated Health Partnerships ${ }^{47}$ and the need to develop multidisciplinary team working is a key recommendation of the proposed NHS workforce strategy. ${ }^{6}$ The need to include interprofessional education (IPE) within prequalifying health professional education is being recognised ${ }^{48-50}$ and conducting postqualification CPD in multidisciplinary teams is central to the proposed integration of strategies from the field of quality improvement into CBME. ${ }^{30}$ This need to develop the healthcare team as a whole recognises that most healthcare occurs in teams and it has been argued that training should recognise that competency and performance need to exist 
at an individual and a collective team level. ${ }^{3451}$ A 2016 review $^{49}$ clearly defined IPE and considered its effects across a wide range of activities: class-based courses, simulation, clinical settings and online learning environments. It summarised the evidence of a positive effect of IPE on learner attitudes/perceptions as well as collaborative knowledge/skills and suggested potential benefits in collaborative behaviours and service improvement. The lack of required interprofessional learning we have identified means that current CPD may not be incorporating this growing evidence base or contributing to the development of multidisciplinary working and integrated care.

This review indicated that there are significant areas where there are gaps in the research. Further investigation into the adoption and effects of IPE across the UK health system is needed if the current policy aspirations for the development of multidisciplinary team working are to be informed by evidence. As current CPD requirements evolve, research is needed to inform regulators on how planned learning can be integrated into evolving systems for patient safety, workplace learning, quality improvement and multicredentialing. The challenge of understanding what constitutes effective CPD from the patient, practitioner and health system perspective will need to acknowledge the planned digital future for the NHS workforce ${ }^{52}$ where simulation and virtual learning environments will become more common and new skills will be needed to work in more technologically enabled services.

\section{Limitations}

A limitation of this review is that it only considers the mandatory minimum requirements on professionals for completion of CPD as a requirement of their registration. All the regulators and professional bodies provide a wealth of information and advice on the role of CPD and best practice, a detailed consideration of which would be valuable but beyond the scope of this paper.

A further limitation of this review is the lack of detail about the individual CPD schemes undertaken by Doctors of Medicine, which uniquely for this profession are defined by medical colleges, faculties and employers too numerous to allow for individual consideration. Their regulator, the General Medical Council, and the Academy of Medical Royal Colleges issue broad guidelines on the characteristics of CPD that doctors need to complete, and we have assumed that these are followed by individual schemes. By including guidelines for doctors (and making this assumption), we were able to comment on most of their CPD characteristics with the notable exception of the requirement for group learning. Consequently, in the overall results, we are only able to report the number of all professionals not required to undertake this type of learning rather on the total number required to do so. By including the detail of CPD for doctors, we felt that we were offering as complete as possible an overview of CPD requirements for all healthcare workers in the UK.

It would also be of great interest to place the findings of this review in a global context comparing the detail of other countries well-established CPD systems for health professionals, especially in the requirements for peer-to-peer learning, interprofessional learning and the use of PDPs.

\section{CONCLUSIONS}

In 2019, there were 32 distinct healthcare professional titles regulated by 9 statutory regulators. CPD is now a mandatory verified requirement for all of these professions but there is considerable variation in the characteristics of the CPD required of them with only one regulator accrediting CPD activities. There is only partial adoption of potentially more effective modalities, such as peer-to-peer learning and use of PDPs and very little requirement for IPE. Reflection on learning undertaken is commonplace but reflection on future learning needs, a defining feature of CPD, is not yet a requirement for most UK health professionals.

\section{Twitter Alison Bullock @CUREMeDE}

Acknowledgements The authors would like to thank Mrs Zoe Young BSc (Hons) MSc (ECON) Specialist Subject Librarian Cardiff University Library, for her help with our choice of databases to search.

Contributors MK is the lead author, responsible for the conception of the work, data acquisition, data analysis and final interpretation. He wrote the initial draft and then has led the process of revising and critically apprising subsequent drafts. NJLS, BR and AB are coauthors, making a substantial contribution to the conception of the work, data analysis and final interpretation. RVN is coauthor, making a substantial contribution to the data analysis, and final interpretation. NJLS, BR, AB and RVN contributed to the process of revising and critically apprising subsequent drafts. All authors have approved the final draft and agreed to be accountable for all aspects of the work ensuring that any questions related to the accuracy or integrity of any part of the work are appropriately investigated and resolved.

Funding The authors have not declared a specific grant for this research from any funding agency in the public, commercial or not-for-profit sectors.

Competing interests None declared.

Patient consent for publication Not required.

Provenance and peer review Not commissioned; externally peer reviewed.

Data availability statement All data relevant to the study are included in the article or uploaded as supplementary information.

Open access This is an open access article distributed in accordance with the Creative Commons Attribution Non Commercial (CC BY-NC 4.0) license, which permits others to distribute, remix, adapt, build upon this work non-commercially, and license their derivative works on different terms, provided the original work is properly cited, appropriate credit is given, any changes made indicated, and the use is non-commercial. See: http://creativecommons.org/licenses/by-nc/4.0/.

ORCID iD

Marek Karas http://orcid.org/0000-0001-9939-6604

\section{REFERENCES}

1 NHS England. Five year forward view. London: NHS England, 2014.

2 Department of Health. Health and well being 2026: delivering together. London: DOH, 2016.

3 Scottish Government. A national clinical strategy for Scotland. Edinburgh: Scottish Goverment, 2016.

4 Welsh Government. A healthier Wales: our plan for health and social care. Cardiff: Welsh Goverment, 2018.

5 NHS England. The NHS long term plan. London: NHS England, 2019.

6 Public Health England. Facing the facts, shaping the future. Public Health England, 2017.

7 Health and Safety Executive. Who regulates health and social care, 2018. Available: http://www.hse.gov.uk/healthservices/ arrangements.htm [Accessed 1 Dec 2019].

8 Department of Health. NHS constitution. London: DOH, 2009. 
9 Department of Health. Promoting professionalism, reforming regulation. A paper for consultation, 2017. Available: https://www. gov.uk/government/consultations/promoting-professionalismreforming-regulation [Accessed 19 Mar 2019].

10 Peck C, McCall M, McLaren B, et al. Continuing medical education and continuing professional development: international comparisons. BMJ 2000;320:432-5.

11 Tran D, Tofade T, Thakkar N, et al. Us and international health professions' requirements for continuing professional development. Am J Pharm Educ 2014;78:129.

12 Bates I, Bruno A, Tofade T, et al. Continuing Professional Development \& Continuing Education in Pharmacy: Global Report. The Hague: FIP, 2014.

13 Marshall G, Punys V, Sykes A. The continuous professional development (CPD) requirements of radiographers in Europe: an initial survey. Radiography 2008;14:332-42.

14 Round WH. Continuing professional development systems for medical physicists: a global survey and analysis. Phys Med 2013;29:261-72.

53 NHS. Foot problems and the podiatrist, 2018. Available: https:// www.nhs.uk/live-well/healthy-body/foot-problems-and-thepodiatrist/ [Accessed 1 Dec 2019].

16 The British Association of Prosthetists and Orthotists. Who are Prosthetists and Orthotists? 2018. Available: https://www.bapo. com/about-us/who-are-prosthetists-and-orthotists/ [Accessed 8 Mar 2019].

17 Medical Act, 1983. Available: https://www.legislation.gov.uk/ukpga/ 1983/54/contents [Accessed 11 Sep 19].

18 Academy of Medical Royal Colleges. Continuing professional development. Guidelines for recommended headings under which to describe a College or faculty CPD scheme. London: AMRC, 2009.

19 Barr H. Interprofessional education: today, yesterday and tomorrow: a review, 2002. 2002, 2002.

20 Full Fact. How many NHS employees are there? 2018. Available: https://fullfact.org/health/how-many-nhs-employees-are-there/ [Accessed 8 Mar 2019].

21 Secretary of State for Health. Trust, assurance and safety: the regulation of health professionals in the 21st century. Vol 7013. London: The Stationery Office, 2007.

22 Department of Health. Safeguarding Patients-the Government's response to the Shipman Inquiry's fifth report and the recommendations of the Ayling, Neale and Kerr/Haslam Inquiries. London: The Stationery Office, 2007.

23 Pickett L. Professional regulation in health and social care. London: House of Commons Library, 2017.

24 Ross MK, Ibbetson RJ. Educational needs and employment status of Scottish dental nurses. Br Dent J 2006;201:661-6.

25 Mercer P, Bailey H, Cook P. Perceptions, attitudes and opinions of general dental practitioners and dental nurses to the provision of lifelong learning for the dental team. Br Dent J 2007;202:747-53.

26 Donyai P, Herbert RZ, Denicolo PM, et al. British pharmacy professionals' beliefs and participation in continuing professional development: a review of the literature. Int $\mathrm{J}$ Pharm Pract 2011;19:290-317.

27 Moons K, Evans S, Lightowlers M, et al. Dental nurses' perception of CPD in Wales. Vital 2012;9:19-23.

28 Henwood SM, Yielder J, Flinton D. Radiographers attitudes to mandatory CPD: a comparative study in the United Kingdom and New Zealand. Radiography 2004;10:251-8.

29 Lockyer J, Bursey F, Richardson D, et al. Competency-Based medical education and continuing professional development: a conceptualization for change. Med Teach 2017;39:617-22.

30 Sargeant J, Wong BM, Campbell CM. Cpd of the future: a partnership between quality improvement and competency-based education. Med Educ 2018;52:125-35.

31 Rouse MJ. Continuing professional development in pharmacy. Pharm Technol 2004;20:303-6.

32 Driesen A, Verbeke K, Simoens S, et al. International trends in lifelong learning for pharmacists. Am J Pharm Educ 2007;71:52.

33 du Boulay C. From CME to CPD: getting better at getting better? BMJ 2000;320:393-4.

34 Links MJ. Beyond competency-based continuing professional development. Med Teach 2018;40:253-8.

35 Gibbs V. An investigation into the challenges facing the future provision of continuing professional development for allied health professionals in a changing healthcare environment. Radiography 2011;17:152-7.

36 Schostak J, Davis M, Hanson J, et al. 'Effectiveness of continuing professional development' project: a summary of findings. Med Teach 2010;32:586-92.
37 Cervero RM, Gaines JK. The impact of CME on physician performance and patient health outcomes: an updated synthesis of systematic reviews. J Contin Educ Health Prof 2015;35:131-8.

38 Forsetlund L, Bjørndal A, Rashidian A, et al. Continuing education meetings and workshops: effects on professional practice and health care outcomes. Cochrane Database Syst Rev 2009:CD003030.

39 Giguère A, Légaré F, Grimshaw J, et al. Printed educational materials: effects on professional practice and healthcare outcomes. Cochrane Database Syst Rev 2012;10:CD004398.

40 Wallace S, May SA. Assessing and enhancing quality through outcomes-based continuing professional development (CPD): a review of current practice. Vet Rec 2016;179:515-20.

41 Chief Executives of statutory regulators of health and care professionals. Benefits of becoming a reflective practitioner. A joint statement of support from chief executives of statutory regulators of health and care professionals, 2019.

42 Department of Health. Working Together-Learning together. A framework for lifelong learning for the NHS. London: Department of Health, 2001.

43 Health Education England. Establishing common standards for continuing professional development, assessment and appraisal guidelines for medical associate professionals, 2019.

44 Challis M. AMEE medical education guide No. 19: personal learning plans. Med Teach 2000;22:225-36.

45 Norcini JJ, Boulet JR, Opalek A, et al. Response to letters for doctors further from medical school graduation. Med Educ 2017;51:977.

46 Ibrahim JE. Continuing professional development: a burden lacking educational outcomes or a marker of professionalism? Med Educ 2015;49:240-2.

47 Ham C. Making sense of integrated care systems, integrated care partnerships and accountable care organisations in the NHS in England, 2018. Available: https://www.kingsfund.org.uk/ publications/making-sense-integrated-care-systems [Accessed 2 Jan 2019].

48 World Health Organization. Framework for action on interprofessional education and collaborative practice. Geneva: World Health Organization, 2010.

49 Reeves S, Fletcher S, Barr H, et al. A BEME systematic review of the effects of interprofessional education: BEME guide No. 39. Med Teach 2016;38:656-68.

50 Steven K, Howden S, Mires G, et al. Toward interprofessional learning and education: mapping common outcomes for prequalifying healthcare professional programs in the United Kingdom. Med Teach 2017;39:720-44.

51 Lingard L, Truths P. Paradoxical truths and persistent myths: Reframing the team competence conversation. $J$ Contin Educ Health Prof 2016;36(Suppl 1):S19-21.

52 Topol E. The Topol review: preparing the healthcare workforce to deliver the digital future. Leeds: HEE [Google Scholar], 2019.

53 General Chiropractic Council. About us, 2018. Available: http:// www.gcc-uk.org/about-us/ [Accessed 25 Jun 2019].

54 General Chiropractic Council. Annual registration report 2017. London; 2018.

55 General Dental Council. Registration Report- January 2019. London General Dental Council; 2019.

56 General Medical Council. Registration and licensing. London; 2018.

57 General Medical Council. The register, 2019. Available: https://data. gmc-uk.org/gmcdata/home/\#/reports/The\%20Register/Stats/report [Accessed 1 Feb 2019].

91 General Osteopathic Council. About us, 2018. Available: https:// www.osteopathy.org.uk/about-us/ [Accessed 1 Dec 2019].

59 General Osteopathic Council. Statistics, 2019. Available: https:// www.osteopathy.org.uk/news-and-resources/research-surveys/ statistics/ [Accessed 1 Feb 2019].

60 Nursing and Midwifery Council. Our role, 2018. Available: https:// www.nmc.org.uk/about-us/our-role/ [Accessed 1 Dec 2019].

61 Nursing and Midwifery Council. The NMC register, 2019. Available: https://www.nmc.org.uk/globalassets/sitedocuments/otherpublications/nmc-register-data-march-19.pdf [Accessed 27 Sep 2019].

62 General Optical Council. Introduction to the GOC, 2018. Available: https://www.optical.org/en/about_us/introduction_to_the_goc/ index.cfm [Accessed 1 Dec 2019].

63 General Pharmaceutical Council. About us, 2018. Available: https:// www.pharmacyregulation.org/about-us [Accessed 1 Dec 2019].

64 Pharmaceutical Society of Northern Ireland. About us, 2018. Available: http://www.psni.org.uk/psni/ [Accessed 1 Dec 2019].

65 Health and Care Professions Council. Registrant snapshot December 2018, 2019. Available: https://www.hcpc-uk.org/ 
resources/data/2018/registrant-snapshot-december-2018/ [Accessed 1 Feb 2019].

66 General Chiropractic Council. Continuing professional development guidance for CPD year 2018/19., 2019. Available: https://www.gccuk.org/assets/publications/CPD_guidance2018_19.pdf [Accessed 1 Dec 2019].

67 General Dental Council. Enhanced CPD guidance, 2018. Available: https://www.gdc-uk.org/docs/default-source/enhanced-cpdscheme-2018/enhanced-cpd-guidance-for-professionals.pdf? sfvrsn=edbe677f_4 [Accessed 1 Dec 2019].

68 General Medical Council. Continuing professional development. Guidance for all doctors. Manchester: GMC, 2014.

69 Academy of Medical Royal Colleges. CPD reflective note guidance and template, 2010. Available: http://www.aomrc.org.uk/reportsguidance/cpd-reflective-note-guidance-template/ [Accessed 1 Dec 2019].

70 Academy of Medical Royal Colleges. Core principles for continuing professional development, 2016. Available: http://www.aomrc.org. uk/wp-content/uploads/2016/07/Core_Principles_CPD_0716-2.pdf [Accessed 1 Dec 2019].

71 General Osteopathic Council. Continuing professional development guidance. London: GOC, 2018.

72 General Osteopathic Council. Planning your CPD workbook. London: GOC, 2018.

73 Nursing and Midwifery Council. Revalidation. London: NMC, 2019.

74 General Optical Council. Continuing education and training (CET) a guide for registrants in the 2019-21 CET cycle. London: GOC, 2019.

75 General Pharmaceutical Council. Revalidation framework. London: GPhC, 2018.

76 Pharmaceutical Society of Northern Ireland. CPD standards and framework. Vol 2019. Belfast: PSNI, 2014.

77 Pharmaceutical Society of Northern Ireland. CPD assessment guide. Belfast: PSNI, 2017.

78 Health and Care Professions Council. Information of registrants. Continuing professional development and your registration. London: HCPC, 2017.

79 Health Professions Council. Continuing professional development audit report 2009-11. London: HPC, 2012.

80 General Medical Council. Guidance on supporting information for appraisal and revalidation. Manchester: GMC, 2018.

81 Institute of Biomedical Science. What is CPD, 2019. Available: https://www.ibms.org/cpd/ [Accessed 25 Jun 2019].

82 The College of Podiatry. Continual professional development (CPD), 2019. Available: https://cop.org.uk/assistant-practitioners/ continued-professional-development/ [Accessed 25 Jun 2019].

83 British Chiropody and Podiatry Association. Welcome to the British Chiropody and podiatry association, 2019. Available: https://bchauk.org/ [Accessed 25 Jun 2019].

84 The Institute of Chiropodists and Podiatrists. Continual professional development (CPD), 2019. Available: https://iocp.org.uk/coursesevents/continual-professional-development-cpd/ [Accessed 25 Jun 2019].

85 Association of Clinical Scientitists. HPC CPD requirements, 2019. Available: http://www.assclinsci.org/acsNews/06-10-11/HPC_CPD_ Requirements.aspx [Accessed 25 Jun 2019].
86 British Dieticians Association. HCPC audit, 2019. Available: https:// www.bda.uk.com/practice-and-education/education/your-cpd/ hcpc-audit.html [Accessed 25 Jun 19].

87 British Society of Hearing Aid Audiologists. HCPC. Available: https://www.bshaa.com/HCPC [Accessed 25 Jun 2019].

88 Royal College of Occupational Therapists. CPD @ RCOT, 2019. Available: https://www.rcot.co.uk/cpd-rcot [Accessed 24 Jun 2019].

89 College of Operating Department Practitioners - Unison. Education and standards. Available: https://www.unison.org.uk/at-work/ health-care/representing-you/unison-partnerships/codp/ [Accessed 25 Jun 2019].

90 British and Irish Orthoptic Society. Bios support with HCPC CPD audits, 2019. Available: https://www.orthoptics.org.uk/bios-supportwith-hcpc-cpd-audits/ [Accessed 25 Jun 2019].

91 British and Irish Orthoptic Society. Continuing professional development recommendations Birmingham, 2007.

92 College of Paramedics. About us, 2019. Available: https://www. collegeofparamedics.co.uk/about_us [Accessed 25 Jun 2019].

93 Chartered Society of Physiotherapy. CPD FAQs, 2019. Available: https://www.csp.org.uk/professional-clinical/cpd-and-education/ cpd-advice/cpd-faqs [Accessed 25 Jun 19].

61 The British Psychological Society. Best practice in CPD, 2019. Available: https://www.bps.org.uk/psychologists/professionaldevelopment/best-practice-cpd [Accessed 1 Dec 2019].

95 Association of Educational Psychologists. Essential requirements for practising as an educational psychologist, 2019. Available: https://www.aep.org.uk/careers/ [Accessed 25 Jun 2019].

96 British Association of Prosthetists \& Orthotists. About us, 2019. Available: https://www.bapo.com/about-us/ [Accessed 25 Jun 2019].

97 Society of Radiographers. Continuing professional development: professional and regulatory requirements. Available: https:// www.sor.org/learning/document-library/continuing-professionaldevelopment-professional-and-regulatory-requirements/3-rationaleand [Accessed 25 Jun 2019].

98 Royal College of Speech and Language Therapists. Continuing professional development:A toolkit for speech and language therapists and assistants 2017. Available: https://www.rcslt. org/-/media/Project/RCSLT/cpd-toolkit-updated-june-2017.pdf [Accessed 1 Dec 2019].

99 General Chiropractic Council. Guidance on checking continuous professional development returns for 2016/ 17 and auditing requirements. London: GCC, 2017.

100 General Medical Council. Guidance for doctors: requirements for revalidation and maintaining your licence. Manchester: GMC, 2018.

101 General Medical Council. Get the MyCPD app, 2018. Available: https://www.gmc-uk.org/education/standards-guidance-andcurricula/guidance/continuing-professional-development/get-themy-cpd-app [Accessed 8 Mar 2019].

102 Nursing and Midwifery Council. Guidance sheet- e-portfolios and revalidation. NMC, 2017.

103 Health and Care Professions Council. How to renew your registration. London: HCPC, 2017. 